\title{
Seasonal Variations of Groundwater Chemistry in the Basement and Sedimentary Rocks of Ibadan and Lagos Areas, Southwestern Nigeria
}

\author{
Anthony Temidayo Bolarinwa ${ }^{1}$ \\ ${ }^{1}$ Department of Geology, University of Ibadan, Ibadan, Nigeria \\ Correspondence: Anthony Temidayo Bolarinwa, Department of Geology, University of Ibadan, Ibadan, Nigeria. \\ E-mail: atbola@yahoo.com
}

Received: September 15, 2016

Accepted: October 3, 2016

Online Published: October 21, 2017

doi:10.5539/esr.v7n1p55

URL: https://doi.org/10.5539/esr.v7n1p55

\begin{abstract}
Hydrochemical investigation of forty boreholes drilled on the basement and sedimentary rocks in Ibadan and Lagos metropolis southwestern Nigeria respectively were carried out in order to determine the portability of the groundwater in both areas and to highlight differences in their chemical characters and variations with seasons. Data obtained indicated that the groundwater in Ibadan area is mainly the $\mathrm{Na}+\mathrm{Ca}-\mathrm{HCO}_{3}$ type, while that of Lagos is $\mathrm{Na}+\mathrm{Ca}-\mathrm{C} 1+\mathrm{SO}_{4}$ type. The groundwater chemistry reflects weathering of sodic plagioclase feldspars in the basement rocks as well as arkosic sandstone in the sedimentary terrain. The higher chloride (ca. $124.2 \mathrm{mg} / \mathrm{L}$ ) content of the Lagos water is probably due to salt-water intrusion along the coastal area. Elevated $\mathrm{Na}^{+}(58.5-$ 1021.2), $\mathrm{Fe}^{2+}(0.3-2.8)$ and $\mathrm{Mn}^{2+}(0.04-2.34) \mathrm{mg} / \mathrm{L}$ concentrations, particularly during the dry season, adversely affect the portability of the water from both localities. Apart from making the water unsuitable for irrigation, high $\mathrm{Na}^{+}$content is considered harmful to persons suffering from cardiac, renal and circulatory diseases. The $\mathrm{Fe}^{2+}$ and $\mathrm{Mn}^{2+}$ contents could also create staining problem. It is therefore desirable to remove these elements from the borehole water prior to consumption.
\end{abstract}

Keywords: groundwater chemistry, weathering, water portability, irrigation

\section{Introduction}

\subsection{Background and Objective}

Harnessing groundwater for developmental purposes require adequate knowledge of the geologic and chemical properties of the aquifers. In southwestern Nigeria, groundwater is abstracted mostly through hand-dug wells and boreholes in both the basement and sedimentary terrains. Apart from the geochemical influence of the bedrock on the chemical quality of groundwater, contaminations of shallow wells from anthropogenic source are common occurrences. Ibadan and Lagos areas (Figure 1) occur within the tropical region characterized by wet and dry seasons. Groundwater recharge during the rainy season in April to October is followed by drawdown in November to March due to paucity of rain, water abstraction coupled with evaporation and transpiration.

Urban cities are prone to waterborne diseases such as cholera, diarrhea and typhoid fever. Air and water pollution are some of the potential hazards in such area. Apart from water borne diseases especially gastro enteritis, which is related to fecal pollution and inadequate hygiene in Ibadan and Lagos areas, toxic elements in soil and rocks may be leached into groundwater. Despite the immense benefits of increased irrigation for food production most especially during the dry season (Kemp \& Hafi 2001), there are reported cases of excess intake of inorganic compound from drinking water in Africa and most especially nitrate in agricultural areas with heavy use of fertilizers (UNESCO, 1997-1998). Aesthetic problems such as bad odour, taste or staining caused by iron, hydrogen sulphide and manganese may adversely affect optimum utilization of groundwater.

Groundwater in Lagos metropolis is vulnerable to contamination due to the permeability of the overlying vadose zones. Aspects of groundwater in both Ibadan and Lagos areas have been studied by many workers including Asseez, (1971); Kampsax-Kruger \& Sshwed Associates, (1977); Loehnert, (1981); Offodile, (1983); Oteri, (1989); Onwuka, (1989, 1990); Ako et al., (1990); Annor et al., (1990); Olayinka, (1992), Olarewaju et al., (1997) and Idowu et al., (1999). However, data from many of such investigations are not usually synthesized with the geology of the area, weathering processes and seasonal variations, which is the focus of the present investigation. 


\subsection{Hydrogeological Setting}

Ibadan metropolis is located on the Precambrian Basement complex rocks of southwestern Nigeria (Figure 1). The major bedrock types include migmatites, banded and granite gneisses, pegmatites quartzite and quartz schist. Other minor rock types include biotite schist, amphibole schist, quartz and aplite veins (Figure 2). Field studies show that the major rock units in Ibadan area are deeply weathered in some locations, leaving only few rock exposures, around the University of Ibadan, Apata and Alakia areas. These rock bodies are foliated and highly fractured as shown in Figure 2. The hydrogeology of the area is primarily controlled by secondary porosity in form of fractures. Although the joints, faults and foliation traces have slightly different orientations due to the polycyclic nature of the basement, the general trend is NW-SE while the dip ranges from 20 to $60^{\circ}$ to the East (Figure 2). Well data from the area shows that the fractured aquifer provides most of the well water, although, saturated unconsolidated overburden of between 10-30m thick seldom occurs.

The Lagos area is located on the Recent alluvial sediments and the Quaternary coastal plain sands, also known as, the Benin Formation (Figures 3 and 4). Stratigraphic and hydrogeological studies by Jones and Hockey (1964), Fayose (1970), Kampsax-Kruger \& Sshwed Associates (1977), Omatsola \& Adegoke (1981), Agagu (1985) and Onwuka (1990) showed that the Quaternary sediments are underlain by Cretaceous and Tertiary rocks (Figure 4). The main rock units are conglomerate, sandstone, limestone, clay, shale and alluvial sand (Figure 4). On the basis of the aquifer types, the sedimentary area is classified into three main hydrographic units namely, the upper, middle and lower aquifers. The uppermost aquifer is composed of weakly consolidated, variedly ferruginised medium to coarse grained Quaternary sands and clays of the Benin Formation. The aquifer varies in thickness from about 90 $\mathrm{m}$ at Abule-Egba to about $150 \mathrm{~m}$ at Mushin. In areas where aquitads are absent, the surfacial aquifer provides recharge for deeper aquifers in the Tertiary sediments below. The Benin Formation forms an extensive unconfined aquifer, which underlies most part of the Lagos metropolis (Figure 2). The upper aquifer is separated from the middle aquifer by a band of greenish laminated Akinbo shale. The underlying aquifer consists of Tertiary limestone and marls of the Ewekoro Formation. At lkeja, the depth to the limestone aquifer is about $160 \mathrm{~m}$. The aquifer is characterized by intercalations of fissile shale, which may hinder the continuity of the aquifer at depth. The third and lowermost hydrographic unit is the Abeokuta Formation. It is composed of Cretaceous conglomerates, coarsegrained feldspathic sandstones and arkoses. The lithology is ferruginised to different degrees inland. The thickness of the aquifer increases from the basement area in the north to the seaward side in the south. Idowu et al. (1999) reported that a borehole at Sango-Otta tap the aquifer within the Abeokuta Formation at $420 \mathrm{~m}$ depth. Six boreholes around Ikeja, with an average depth of about $720 \mathrm{~m}$ were reported to have tapped hot water (Onwuka, 1989).

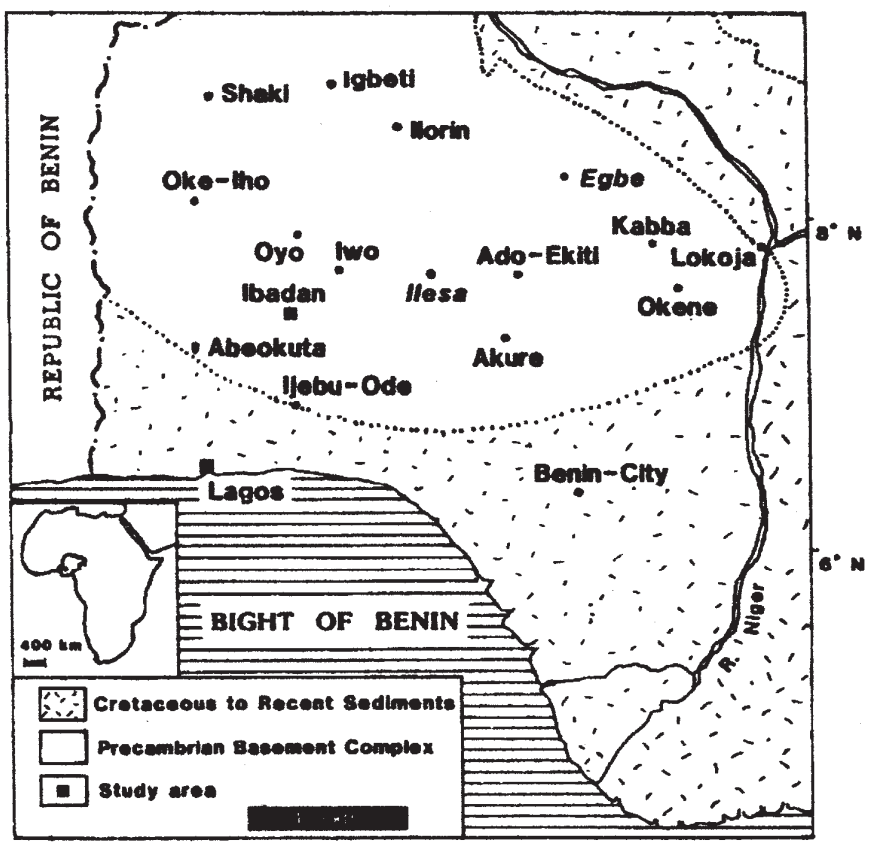

Figure 1. Location map of Ibadan and Lagos areas 


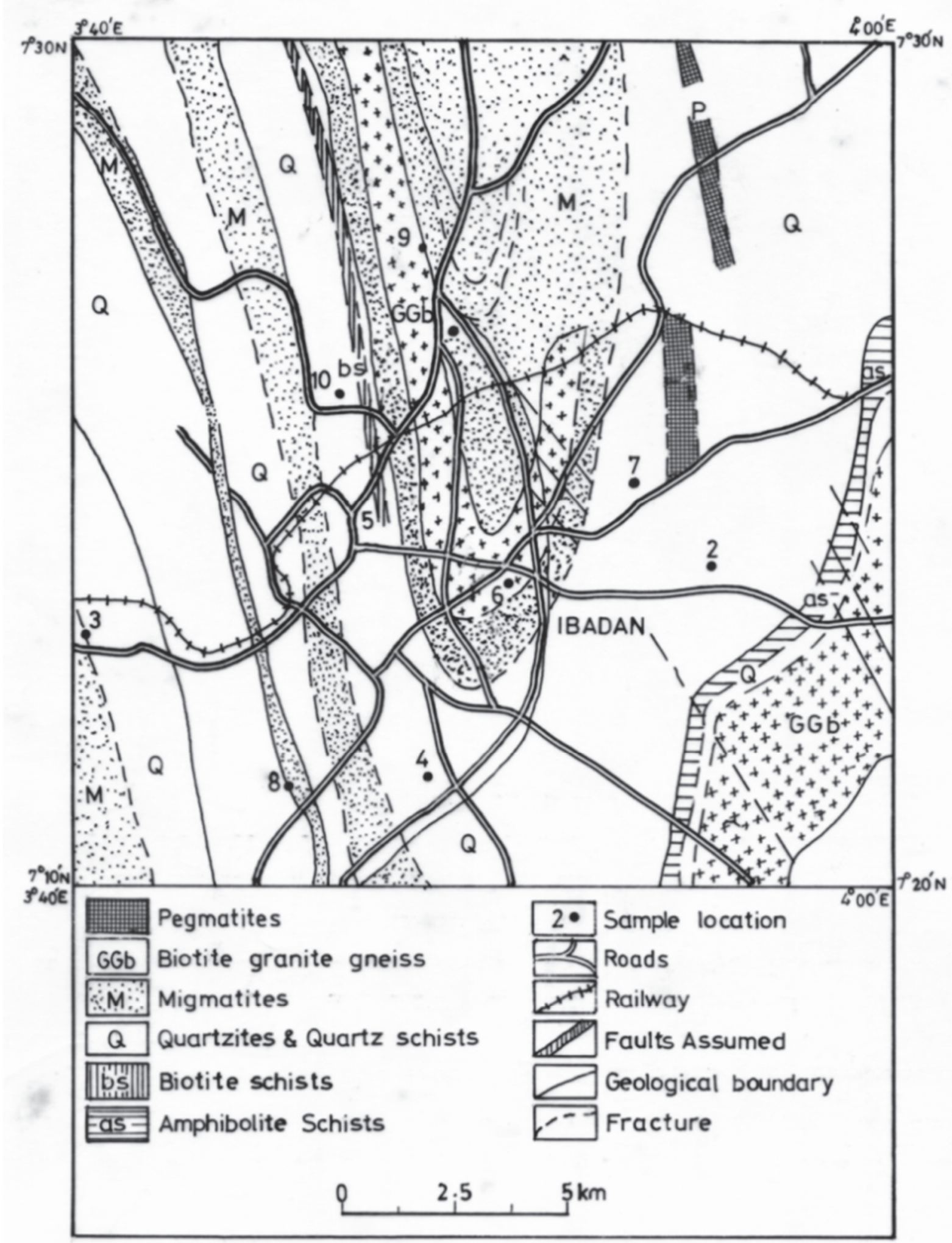

Figure 2. Geological map of Ibadan area showing sample locations

1 - Agbowo 2-Alakia3 - Apata 4-Boluwaji 5-Cocacola

6-Iwo-Road 7 -Monatan $\quad 8$-New Garage $\quad 9$-Ojoo 10 -Polytechnic 


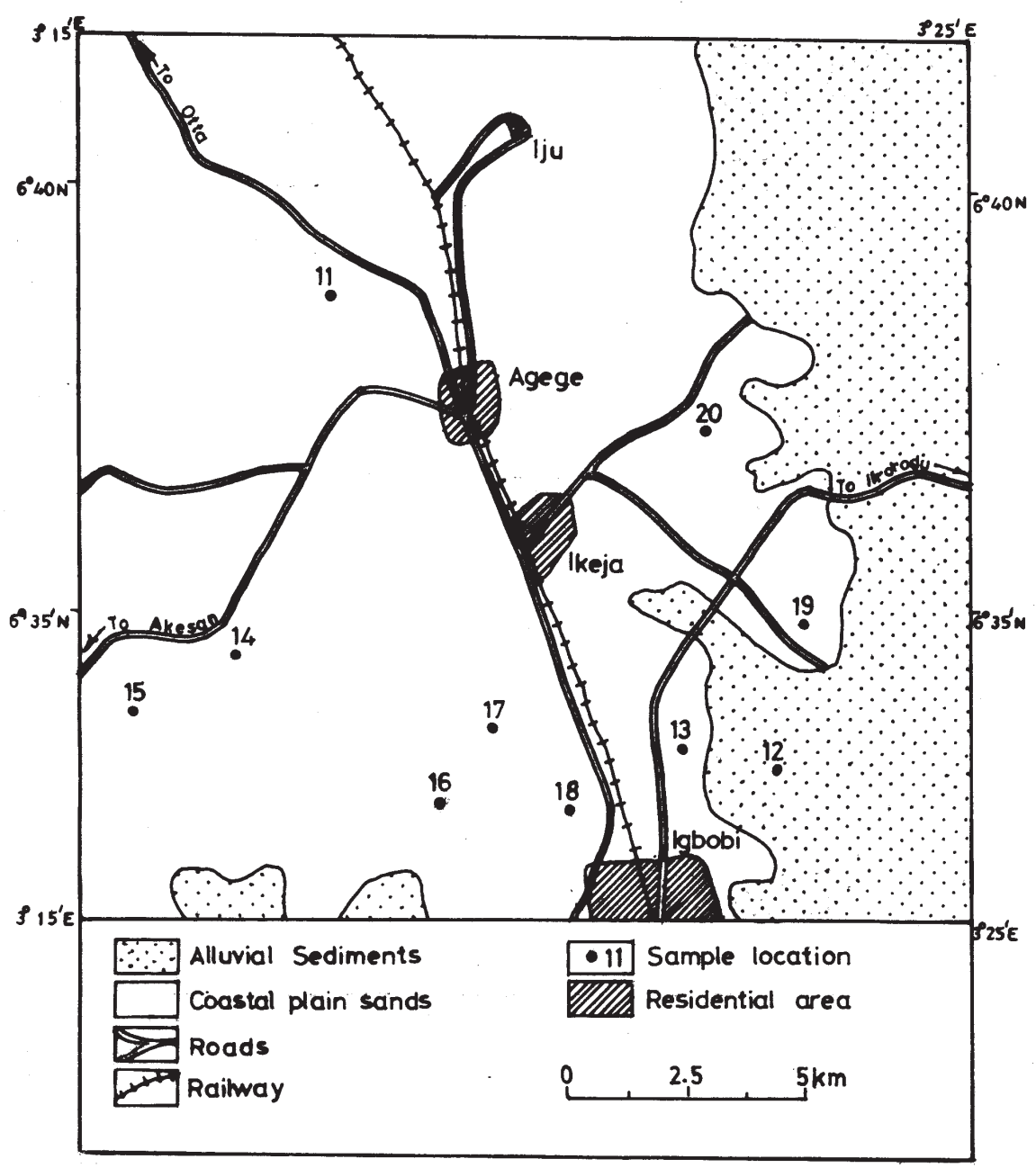

Figure 3. Geological map of Lagos area showing sample locations
11 - Abule Egba
12 - Bariga
13 - Gbagada 14 - Idimu
15 - Ikotun
16 - Isolo 17 - Mafoluku 18-Mushin 19-Ogudu 20-Shangisha

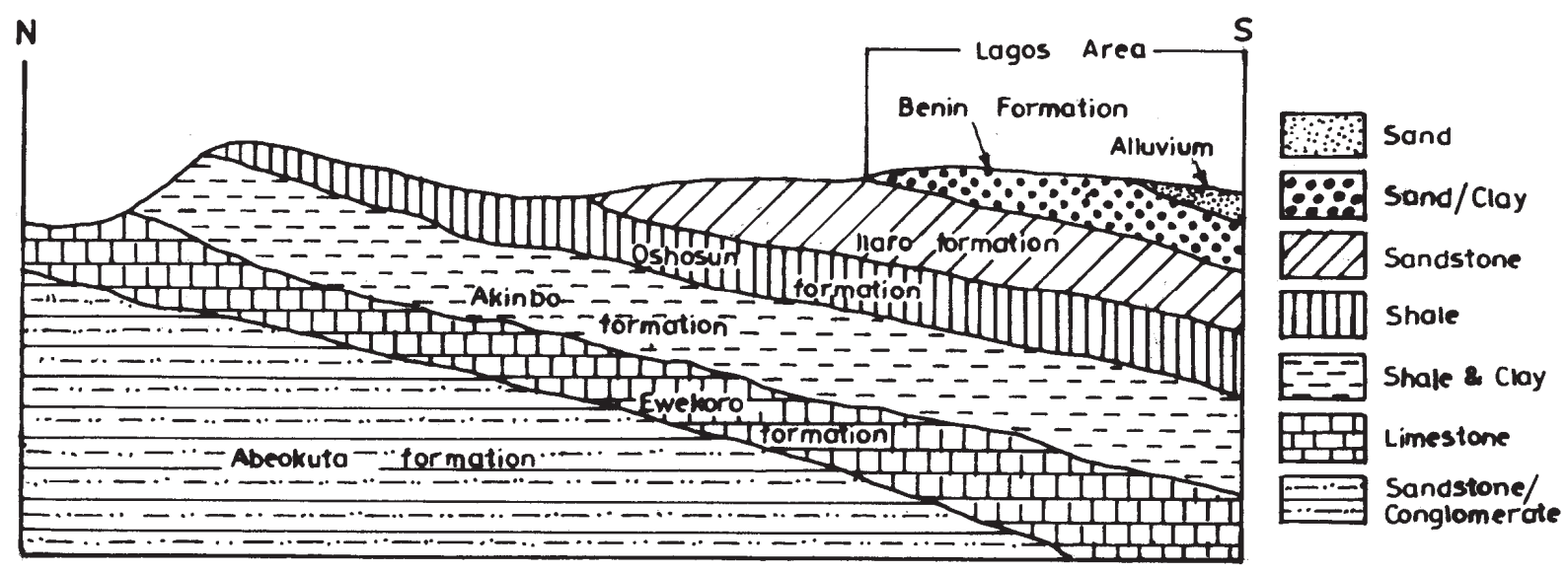

Figure 4. Lithologic section of the sedimentary rocks in Lagos area

\section{Materials and Methods}

A total of forty borehole water samples were collected from twenty locations within lbadan and Lagos metropolis 
(Figures $2 \& 3$ ). Twenty samples each were collected during the dry season (January - February) and wet season (June - July) from both areas. Each borehole was sampled by pumping with an electric submersible pump. Temperature and $\mathrm{pH}$ were measured at the sampling site. Separate samples were collected for the analysis of major cations notably $\mathrm{Ca}^{2+}, \mathrm{Mg}^{2+}, \mathrm{Na}^{+}, \mathrm{K}^{+}, \mathrm{Mn}^{2+}, \mathrm{Fe}^{2+}$ and $\mathrm{Cu}^{2+}$. Anion determinations include $\mathrm{CO}_{3}{ }^{2+}, \mathrm{HCO}_{3}{ }^{2-}, \mathrm{SO}_{4}{ }^{2-}, \mathrm{Cl}^{-}$ and $\mathrm{NO}_{3}{ }^{2-}$. Filtering of the water samples was accomplished with $0.45 \mathrm{~mm}$ cellulose acetate filters. The water samples were stored in a refrigerator after addition of preservative chemicals $\left(\mathrm{HNO}_{3}\right)$. Laboratory analyses were conducted within 24 hours after sampling, in the Chemistry Department, University of lbadan. Spectrophotometric as well as titration methods were employed following the procedures of Brown et al. (1970) and APHA, (1981). The colour of the water samples was determined using the Lovibond Nesslerisser Comparator and expressed in Hazen units.

\section{Results}

Results of the physico-chemical analyses of the water samples are presented in Tables 1 and 2. Table 3 summarises the values in the basement and sedimentary area with a comparison to the World Health Organization (WHO) and the Commission of European Communities (CEC) recommended standards. The result shows that the depth of water level ranged from 0.5 to $15.0 \mathrm{~m}$ in the basement of Ibadan and 0.2 to $5.0 \mathrm{~m}$ in the sedimentary area of Lagos. Borehole depths were between 10.5 to $33.0 \mathrm{~m}$ in lbadan and 80 to $200 \mathrm{~m}$ in Lagos area. The colour of the basement water ranged between 1 to $5 \mathrm{HU}$ while the sedimentary derived water varies from 5 to $50 \mathrm{HU}$. Total dissolved solids (TDS) are relatively higher in the sedimentary water compared to the basement water. Average values of 241 and $120 \mathrm{mg} / \mathrm{L}$ were recorded for both waters respectively.

The chemical composition of the groundwater in the basement area of lbadan is dominated by sodium, calcium bicarbonate ions (Table 1), whereas those of the Lagos sedimentary area is the sodium, calcium chloride and sulphate type (Table 2). The general ionic order of dominance among the cations is $\mathrm{Na}^{+}>\mathrm{K}^{+}>\mathrm{Ca}^{+}>\mathrm{Mg}^{2+}$ in both localities. The $\mathrm{Cl}^{-}$and $\mathrm{SO}_{4}{ }^{2+}$ ions are generally higher in the Lagos water, whereas the lbadan area water is dominated by $\mathrm{HCO}_{3}{ }^{-}$. The variation of the anions and cations for each sample expressed in $\% \mathrm{meq} / \mathrm{L}$ are presented in a Piper trilinear diagram (Figure 5). The diagram show distinct separation of cations into the $\mathrm{Cl}^{-}$and $\mathrm{HCO}_{3}{ }^{-}$ fields for the sedimentary and basement water respectively. The sedimentary samples occur mostly in the $\mathrm{Na}^{+}+$ $\mathrm{CaCl}^{-}+\mathrm{Cl}^{-}-\mathrm{SO}_{4}{ }^{2-}$ ionic fields, while the basement water falls within the $\mathrm{Na}^{+}+\mathrm{Ca}^{2+} / \mathrm{HCO}_{3}{ }^{-}$field. The $\mathrm{Fe}^{2+}$ ion is elevated in most of the shallow boreholes in the Lagos area to about $2.8 \mathrm{mg} / \mathrm{L}$. The $\mathrm{pH}$ values of the water samples from the basement area are between 5.9 and 8.0 while those of the sedimentary area are 5.8 and 7.2. The water bodies in both localities are thus slightly acidic to moderately alkaline. Nitrate concentration range from 0.50 to $18.2 \mathrm{mg} / \mathrm{L}$ in both areas. The sodium absorption ratio (SAR) is higher in the sedimentary water than the basement water (Tables $1 \& 2$ ). The $\mathrm{Pb}^{2+}$ and $\mathrm{Zn}^{2+}$ values are generally below detection limits in all the water samples. In Lagos area, $\mathrm{NO}_{3}{ }^{-}$and $\mathrm{SO}_{4}{ }^{2-}$ concentrations in some of the water samples are higher than those of the Ibadan samples (Table 2). These may suggest contamination of the ground water at these locations through anthropogenic sources.

The variation in water chemistry is consistent with the mineralogy of the bulk-rock samples collected from the area (Bolarinwa, 2001). Petrographic, X-ray diffraction and microprobe analyses of bulk-rock and mineral samples collected from outcrops and vertical sections of hand-dug wells and freshly exposed lateritic profiles in Ibadan area indicate that the weathered basement rocks is composed mainly of kaolinite, quartz, sodic plagioclase feldspars and K-feldspar. Minor amounts of halloysite, geothite, biotite and muscovite are also present (Bolarinwa, 2001). The sandstone and clay-shale lithology of the sedimentary areas of Lagos is dominated by quartz, kaolinite and plagioclase with minor amount of montmorillonite, chlorite and muscovite (Bolarinwa, 2001). Analysis of the data shows that weathering reactions in the aquifer controls the groundwater chemistry. The chemical composition of the water is thus influenced by the climate, geologic environment and mineral stability.

Table 1. Chemical Compositions of the Groundwater in Ibadan and Lagos areas during the dry season (January February)

\begin{tabular}{|c|c|c|c|c|c|c|c|c|c|c|c|c|c|c|c|c|c|}
\hline $\begin{array}{l}\text { Loc. } \\
\text { No. }\end{array}$ & $\begin{array}{l}\text { Location } \\
\text { name }\end{array}$ & $\begin{array}{l}\text { Sample } \\
\text { code }\end{array}$ & $\begin{array}{l}\text { Temp } \\
{ }^{\circ} \mathrm{C}\end{array}$ & $\mathrm{pH}$ & $\begin{array}{l}\text { TDS } \\
\mathrm{mg} / \mathrm{L}\end{array}$ & $\begin{array}{l}\mathrm{Ca}^{2+} \\
\mathrm{mg} / \mathrm{L}\end{array}$ & $\begin{array}{l}\mathrm{Mg}^{2+} \\
\mathrm{mg} / \mathrm{L}\end{array}$ & $\begin{array}{l}\mathrm{Na}^{+} \\
\mathrm{mg} / \mathrm{L}\end{array}$ & $\begin{array}{l}\mathrm{K}^{+} \\
\mathrm{mg} / \mathrm{L}\end{array}$ & $\begin{array}{l}\mathrm{Fe}^{2+} \\
\mathrm{mg} / \mathrm{L}\end{array}$ & $\begin{array}{l}\mathrm{Mn}^{2+} \\
\mathrm{mg} / \mathrm{L}\end{array}$ & $\begin{array}{l}\mathrm{Cu}^{2+} \\
\mathrm{mg} / \mathrm{L}\end{array}$ & $\begin{array}{l}\mathrm{HCO}_{3}^{-} \\
\mathrm{mg} / \mathrm{L}\end{array}$ & $\begin{array}{l}\mathrm{CI}^{-} \\
\mathrm{mg} / \mathrm{L}\end{array}$ & $\begin{array}{l}\mathrm{SO}_{4}{ }^{2-} \\
\mathrm{mg} / \mathrm{L}\end{array}$ & $\begin{array}{l}\mathrm{NO}_{3}^{-} \\
\mathrm{mg} / \mathrm{L}\end{array}$ & $\begin{array}{l}\text { SAR } \\
\mathrm{mg} / \mathrm{L}\end{array}$ \\
\hline \multicolumn{18}{|c|}{ Ibadan (Basement Complex area) } \\
\hline 1 & Agbowo & AG & 28.9 & 6.6 & 350 & 108 & 40.8 & 352.6 & 39.8 & 1.2 & 0.08 & 0.09 & 165 & 120 & 220 & 6.8 & 37.8 \\
\hline 2 & Alakia & $\mathrm{AL}$ & 29.2 & 7.0 & 90 & 44 & 43.2 & 59.2 & 47.8 & 1.9 & 0.38 & 0.06 & 65 & 26 & 95 & 1.2 & 9.0 \\
\hline 3 & Apata & AP & 28.9 & 8.0 & 690 & 96 & 79.2 & 1021.2 & 858.6 & 0.7 & 0.04 & 0.09 & 270 & 378 & 285 & 6.8 & 109.1 \\
\hline 4 & Boluwaji & $\mathrm{BO}$ & 28.8 & 6.7 & 60 & 20 & 7.2 & 58.5 & 79.4 & 2.1 & 0.32 & 0.19 & 55 & 58 & 40 & 1.8 & 15.0 \\
\hline 5 & Cocacola & $\mathrm{CC}$ & 28.9 & 6.8 & 120 & 40 & 19.2 & 69.6 & 40.5 & 1.9 & 0.67 & 0.10 & 65 & 36 & 90 & 3.0 & 12.8 \\
\hline
\end{tabular}




\begin{tabular}{|c|c|c|c|c|c|c|c|c|c|c|c|c|c|c|c|c|c|}
\hline 6 & Iwo-Road & IR & 28.9 & 5.9 & 100 & 8 & 4.8 & 181.3 & 136.1 & 1.5 & 0.81 & 0.12 & 80 & 54 & 20 & 3.2 & 72.5 \\
\hline 7 & Monatan & MO & 28.9 & 6.5 & 120 & 44 & 2.4 & 144.3 & 7.6 & 0.3 & 0.06 & 0.02 & 55 & 40 & 60 & 1.4 & 29.9 \\
\hline 8 & New Garage & NG & 28.7 & 7.5 & 300 & 44 & 31.2 & 318.2 & 119.9 & 1.0 & 0.76 & 0.12 & 40 & 242 & 120 & 4.4 & 51.9 \\
\hline 9 & Ojoo & $\mathrm{OJ}$ & 28.8 & 7.2 & 130 & 32 & 19.2 & 162.8 & 26.7 & 0.5 & 1.26 & 0.10 & 55 & 54 & 80 & 3.2 & 32.0 \\
\hline 10 & Polytechnic & PT & 28.8 & 6.8 & 140 & 48 & 19.2 & 185.0 & 56.6 & 2.3 & 0.22 & 0.07 & 80 & 48 & 75 & 0.8 & 35.2 \\
\hline \multicolumn{18}{|c|}{ Lagos (Sedimentary area) } \\
\hline 11 & Abule-Egba & $\mathrm{AE}$ & 28.9 & 7.2 & 330 & 72 & 43.2 & 322.0 & 105.3 & 2.8 & 0.66 & 0.15 & 80 & 118 & 180 & 3.6 & 42.4 \\
\hline 12 & Bariga & BA & 29.2 & 6.7 & 340 & 52 & 42.0 & 621.6 & 186.3 & 1.1 & 0.47 & 0.11 & 25 & 234 & 90 & 0.8 & 109.9 \\
\hline 13 & Gbagada & GB & 29.0 & 6.6 & 390 & 52 & 36.0 & 314.5 & 102.1 & 1.4 & 0.86 & 0.15 & 60 & 124 & 140 & 1.2 & 47.4 \\
\hline 14 & Idimu & ID & 29.0 & 6.5 & 150 & 8 & 4.8 & 292.3 & 25.9 & 1.8 & 0.38 & 0.21 & 35 & 86 & 20 & 9.0 & 115.5 \\
\hline 15 & Ikotun & IK & 28.8 & 7.0 & 160 & 12 & 24.0 & 288.6 & 27.5 & 2.8 & 0.32 & 0.31 & 35 & 80 & 50 & 8.6 & 68.0 \\
\hline 26 & Isolo & IS & 28.8 & 5.8 & 160 & 12 & 12.0 & 284.9 & 63.2 & 1.8 & 0.26 & 0.12 & 20 & 120 & 40 & 2.0 & 82.2 \\
\hline 17 & Mafoluku & MA & 29.0 & 7.2 & 130 & 12 & 0.01 & 299.7 & 72.9 & 2.3 & 0.37 & 0.08 & 35 & 60 & 15 & 1.6 & 122.3 \\
\hline 18 & Mushin & $\mathrm{MU}$ & 29.0 & 6.3 & 470 & 20 & 12.0 & 599.4 & 453.5 & 1.0 & 2.34 & 0.12 & 80 & 234 & 50 & 3.4 & 149.9 \\
\hline 19 & Ogudu & $\mathrm{OG}$ & 28.9 & 6.9 & 290 & 16 & 2.4 & 358.9 & 68.45 & 0.6 & 0.34 & 0.09 & 35 & 158 & 25 & 3.6 & 118.3 \\
\hline 20 & Shangisha & $\mathrm{SH}$ & 28.9 & 6.6 & 90 & 12 & 2.4 & 159.1 & 19.4 & 0.6 & 0.53 & 0.07 & 20 & 28 & 20 & 10.8 & 59.3 \\
\hline
\end{tabular}

SAR - Sodium absorption ratio

Table 2. Chemical Compositions of the Groundwater in Ibadan and Lagos areas during the wet season (June -July)

\begin{tabular}{|c|c|c|c|c|c|c|c|c|c|c|c|c|c|c|c|c|c|}
\hline $\begin{array}{l}\text { Loc. } \\
\text { No }\end{array}$ & $\begin{array}{l}\text { Location } \\
\text { name }\end{array}$ & $\begin{array}{l}\text { Sample } \\
\text { code }\end{array}$ & $\begin{array}{l}\text { Temp } \\
{ }^{\circ} \mathrm{C}\end{array}$ & $\mathrm{pH}$ & $\begin{array}{l}\mathrm{TDS} \\
\mathrm{mg} / \mathrm{L} \\
\end{array}$ & $\begin{array}{l}\mathrm{Ca}^{2+} \\
\mathrm{mg} / \mathrm{L}\end{array}$ & $\begin{array}{l}\mathrm{Mg}^{2+} \\
\mathrm{mg} / \mathrm{L} \\
\end{array}$ & $\begin{array}{l}\mathrm{Na}^{+} \\
\mathrm{mg} / \mathrm{L}\end{array}$ & $\begin{array}{l}\mathrm{K}^{+} \\
\mathrm{mg} / \mathrm{L}\end{array}$ & $\begin{array}{l}\mathrm{Fe}^{2+} \\
\mathrm{mg} / \mathrm{L}\end{array}$ & $\begin{array}{l}\mathrm{Mn}^{2+} \\
\mathrm{mg} / \mathrm{L}\end{array}$ & $\begin{array}{l}\mathrm{Cu}^{2+} \\
\mathrm{mg} / \mathrm{L}\end{array}$ & $\begin{array}{l}\mathrm{HCO}_{3}{ }^{-} \\
\mathrm{mg} / \mathrm{L}\end{array}$ & $\begin{array}{l}\mathrm{CI}^{-} \\
\mathrm{mg} / \mathrm{L}\end{array}$ & $\begin{array}{l}\mathrm{SO}_{4}{ }^{2-} \\
\mathrm{mg} / \mathrm{L}\end{array}$ & $\begin{array}{l}\mathrm{NO}_{3}{ }^{-} \\
\mathrm{mg} / \mathrm{L}\end{array}$ & $\begin{array}{l}\text { SAR } \\
\mathrm{mg} / \mathrm{L}\end{array}$ \\
\hline \multicolumn{18}{|c|}{ Ibadan (Basement Complex area) } \\
\hline 1 & Agbowo & AG & 25.5 & 6.9 & 160 & 45 & 32.0 & 62.3 & 12.4 & 0.08 & 0.02 & 0.03 & 66 & 32 & 62 & 8.2 & 10.0 \\
\hline 2 & Alakia & $\mathrm{AL}$ & 26.8 & 7.1 & 4.8 & 28 & 29.4 & 40.2 & 15.8 & 0.09 & 0.14 & 0.02 & 24 & 8 & 32 & 0.5 & 7.5 \\
\hline 3 & Apata & AP & 26.0 & 7.5 & 395 & 52 & 45.5 & 230.0 & 215.0 & 0.05 & 0.01 & 0.04 & 98 & 98 & 85 & 8.6 & 32.9 \\
\hline 4 & Boluwaji & BO & 25.9 & 6.8 & 46 & 15 & 5.0 & 31.4 & 21.5 & 0.05 & 0.01 & 0.08 & 23 & 20 & 12 & 0.8 & 9.9 \\
\hline 5 & Cocacola & $\mathrm{CC}$ & 26.2 & 7.0 & 53 & 21 & 15.9 & 31.6 & 10.0 & 0.01 & 0.25 & 0.06 & 28 & 10 & 26 & 1.2 & 7.4 \\
\hline 6 & Iwo-Road & IR & 26.5 & 6.6 & 61 & 6 & 3.3 & 45.0 & 27.5 & 0.09 & 0.32 & 0.04 & 35 & 15 & 8 & 1.6 & 20.9 \\
\hline 7 & Monatan & MO & 26.0 & 7.0 & 58 & 24 & 2.0 & 31.4 & 19.2 & 0.05 & 0.03 & 0.01 & 39 & 12 & 20 & 0.8 & 8.7 \\
\hline 8 & New Garage & NG & 25.9 & 6.9 & 132 & 26 & 25.2 & 60.9 & 22.7 & 0.07 & 0.25 & 0.05 & 24 & 62 & 42 & 2.9 & 12.0 \\
\hline 9 & Ojoo & OJ & 25.8 & 6.8 & 86 & 20 & 15.5 & 34.3 & 8.3 & 0.05 & 0.46 & 0.04 & 18 & 18 & 21 & 1.5 & 8.1 \\
\hline 10 & Polytechnic & PT & 26.3 & 7.0 & 77 & 32 & 6.0 & 36.7 & 14.0 & 0.52 & 0.08 & 0.02 & 21 & 28 & 26 & 0.5 & 8.4 \\
\hline \multicolumn{18}{|c|}{ Lagos (Sedimentary area) } \\
\hline 11 & Abule Egba & $\mathrm{AE}$ & 26.3 & 7.0 & 155 & 40 & 25.0 & 53.4 & 25.0 & 1.08 & 0.15 & 0.06 & 25 & 49 & 51 & 1.8 & 9.4 \\
\hline 12 & Bariga & BA & 27.0 & 6.9 & 110 & 31 & 9.5 & 86.5 & 39.9 & 0.16 & 0.11 & 0.04 & 8 & 65 & 32 & 0.5 & 19.2 \\
\hline 13 & Gbagada & GB & 27.2 & 6.8 & 164 & 35 & 18.8 & 44.0 & 22.5 & 0.05 & 0.28 & 0.05 & 15 & 44 & 46 & 0.8 & 8.5 \\
\hline 14 & Idimu & ID & 26.5 & 7.0 & 75 & 3 & 2.6 & 35.9 & 6.0 & 0.09 & 0.14 & 0.09 & 9 & 32 & 18 & 14.6 & 21.5 \\
\hline 15 & Ikotun & IK & 26.8 & 6.9 & 88 & 7 & 10.0 & 391 & 8.2 & 1.12 & 0.19 & 0.10 & 10 & 25 & 22 & 16.8 & 13.4 \\
\hline 16 & Isolo & IS & 26.3 & 7.1 & 81 & 6 & 5.8 & 42.8 & 15.9 & 0.09 & 0.09 & 0.04 & 6 & 48 & 23 & 1.2 & 17.6 \\
\hline 17 & Mafoluku & MA & 26.0 & 6.9 & 86 & 8 & 1.2 & 46.0 & 22.1 & 0.68 & 0.15 & 0.02 & 9 & 21 & 16 & 0.8 & 21.4 \\
\hline 18 & Mushin & MU & 27.4 & 6.5 & 230 & 12 & 6.4 & 75.4 & 86.5 & 0.08 & 0.61 & 0.05 & 22 & 72 & 23 & 1.6 & 24.9 \\
\hline 19 & Ogudu & OG & 26.1 & 7.0 & 78 & 9 & 1.6 & 38.7 & 19.8 & 0.06 & 0.08 & 0.05 & 8 & 48 & 22 & 1.9 & 16.8 \\
\hline 20 & Shangisha & $\mathrm{SH}$ & 26.5 & 7.0 & 42 & 6 & 1.2 & 25.9 & 8.7 & 0.05 & 0.17 & 0.03 & 6 & 12 & 13 & 18.2 & 13.7 \\
\hline
\end{tabular}

SAR - Sodium absorption ratio

Table 3. Portability of groundwater in the different geological environments compared with the WHO (1993) and CEC (1980) guidelines

\begin{tabular}{|c|c|c|c|c|c|c|c|c|}
\hline \multirow[b]{2}{*}{ Class } & \multirow[b]{2}{*}{ Parameter } & \multicolumn{4}{|l|}{ This study } & \multirow{2}{*}{$\begin{array}{l}\text { WHO (1993) } \\
\text { Guideline } \\
\text { max. value }\end{array}$} & \multirow{2}{*}{$\begin{array}{l}\text { CEC (1980) } \\
\text { Guideline } \\
\text { value }\end{array}$} & \multirow{2}{*}{$\begin{array}{l}\text { CEC (1980) } \\
\text { Max. admissible } \\
\text { concentration }\end{array}$} \\
\hline & & $\begin{array}{l}\text { Wet Season } \\
\text { Basement }\end{array}$ & Sedimentary & $\begin{array}{l}\text { Dry Season } \\
\text { Basement }\end{array}$ & Sedimentary & & & \\
\hline \multirow[t]{3}{*}{ (A) } & $\mathrm{Cu}^{2+}$ & $0.01-0.08$ & $0.02-0.10$ & $0.02-0.19$ & $0.07-0.31$ & 2.0 & 0.1 & - \\
\hline & $\mathrm{Mn}^{2+}$ & $0.01-0.46$ & 0.08-06-.61 & $0.04-1.26$ & $0.26-2.34$ & 0.5 & 0.02 & 0.05 \\
\hline & $\mathrm{NO}_{3}^{-}$ & $0.5-8.6$ & $0.5-18.2$ & $0.8-6.8$ & $0.8-10.8$ & 50 & 25 & 50 \\
\hline (B) & $\mathrm{Na}^{+}$ & $314-62.3$ & $25.9-86.3$ & $58.5-1021.2$ & $159.1-621.6$ & 200 & 20 & 150 \\
\hline
\end{tabular}




\begin{tabular}{llllllll}
$\mathrm{Ca}^{2+}$ & $6.0-52.0$ & $3.0-40.0$ & $8.0-108.0$ & $8.0-72.0$ & - & 100 & - \\
$\mathrm{Mg}^{2+}$ & $2.0-45.5$ & $1.2-25.0$ & $2.4-79.2$ & $0.01-43.2$ & - & 30 & 50 \\
$\mathrm{~K}^{+}$ & $8.3-215.0$ & $6.0-86.5$ & $26.7-8586$ & $19.4-453.5$ & - & 10 & 12 \\
$\mathrm{Fe}^{2+}$ & $0.05-0.52$ & $0.05-1.12$ & $0.3-2.3$ & $0.6-2.8$ & 0.3 & 0.05 & 0.2 \\
$\mathrm{SO}_{4}^{2-}$ & $8.0-85.0$ & $13.0-51.0$ & $20.0-2850$ & $15.0-180.0$ & 250 & $25-250$ & 250 \\
\hline
\end{tabular}

All values are in milligrams per litre $(\mathrm{mg} / \mathrm{L})$.

(A) - Chemicals of health significance in drinking water.

(B) - Substances in drinking water, although not necessarily harmful to health, may give rise to complaints from consumers

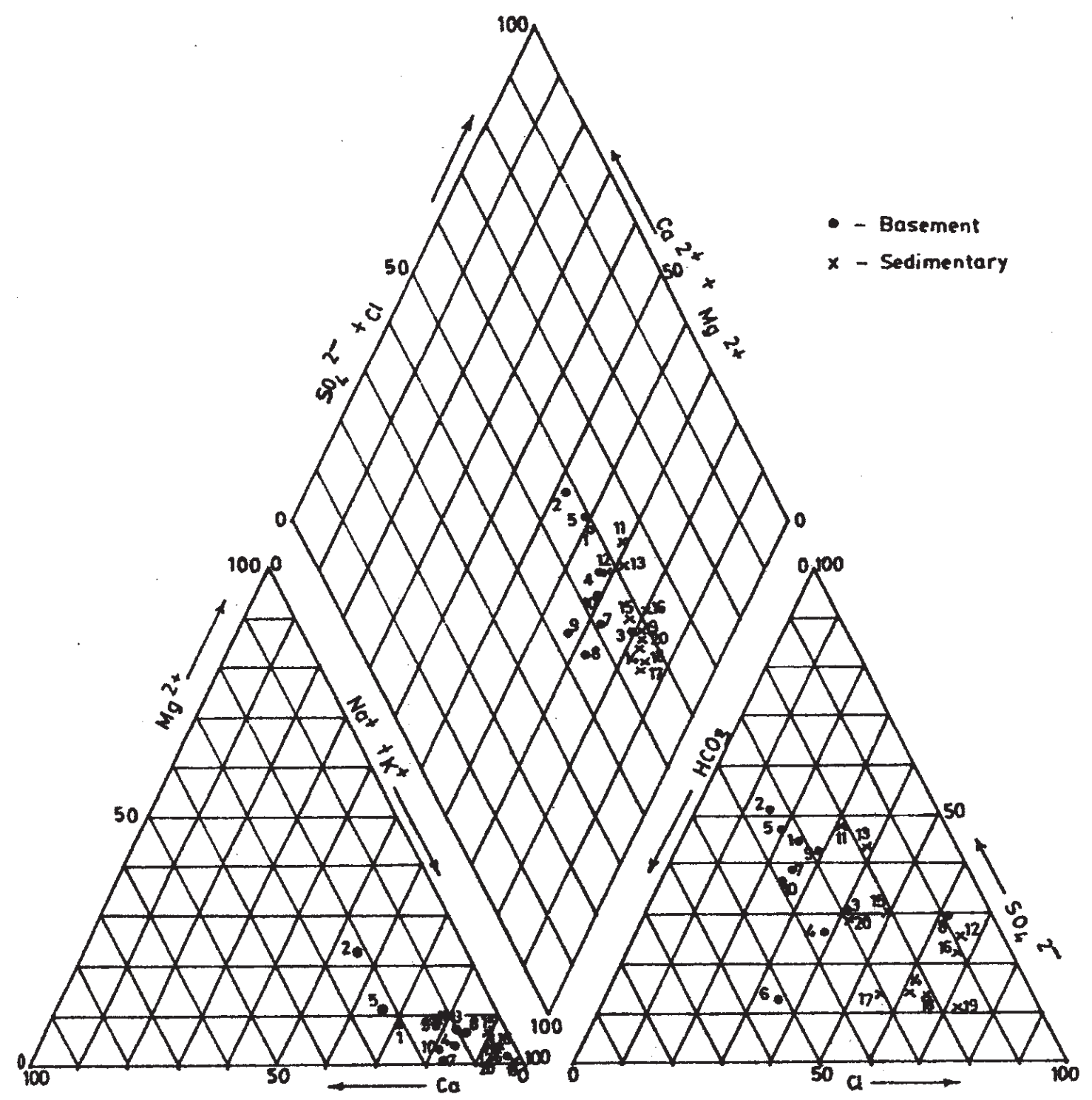

Figure 5. Piper trilinear diagram of the groundwater in Ibadan and Lagos areas.

\section{Discussion}

The mobility of chemical components in underground water depends on their solubility and occurrence as free ions, complexes or molecules and on the environment. Apart from these natural phenomena, human activities also play significant roles on groundwater quality (Appleyard, 1995; Kacaroglu \& Gunay, 1997).

The chemical data presented in Tables 1 and 2 show wide ranges due to differences in the underlying rock types and seasonal changes in water chemistry resulting from recharge during the wet season and drawdown/abstraction 
and evaporation during the dry season. Similar results were obtained by Ako et al., (1990), in the metamorphic terrain of Ile-lfe / Modakeke area, southwestern Nigeria. Chemicals of health significance in drinking water include $\mathrm{As}^{3+}, \mathrm{Cu}^{2+}, \mathrm{Pb}^{2+}, \mathrm{Mn}^{2+}$ and $\mathrm{NO}_{3}{ }^{-}$. Other substances in drinking water, which though not necessarily harmful to health, may give rise to complaints from consumer, include $\mathrm{Ca}^{2+}, \mathrm{Cl}^{-}, \mathrm{Fe}^{2+}, \mathrm{Mg}^{2+}, \mathrm{K}^{+}, \mathrm{Na}^{+}$and $\mathrm{SO}_{4}{ }^{2-}(\mathrm{WHO}, 1984$; 1993; CEC, 1980, Table 3). Weathering of silicate minerals increases the alkalinity of groundwater and concentrations of total dissolved solids (TDS). The dissolution of sodi-potassic feldspars (perthite) or albititic plagioclase feldspar in the pegmatite veins and quartz schist of Apata, New Garage and Agbowo area is responsible for the high $\mathrm{Na}^{+}$and $\mathrm{K}^{+}$contents in the groundwater. Furthermore, $\mathrm{Mg}^{2+}, \mathrm{SO}_{4}{ }^{2-}, \mathrm{Cl}^{-}$, TDS and $\mathrm{pH}$ values are relatively higher in Apata area, due to the probable occurrence of the water in the intermediate zone, which lack intensive circulation. Loehnert (1981) attributed this condition to limited groundwater replenishment in such areas. The low values of $\mathrm{Ca}^{2+}, \mathrm{Mg}^{2+}$ and $\mathrm{K}^{+}$in some of the basement and sedimentary sites may be due to localized ion exchange and precipitation of secondary clay minerals such as chlorite and kaolinite within fractures and intergranular pores within the bedrock (Archeampong \& Hess, 1998). These could be responsible for the low porosity and permeability of the aquifers. This is evident in the low yield recorded in some of the boreholes in these areas. The higher $\mathrm{Na}^{+}$and $\mathrm{Cl}^{-}$concentration in the aquifers of the sedimentary area may be due to salt-water intrusion (Oteri, 1989). Higher $\mathrm{Ca}^{2+}(108 \mathrm{mg} / \mathrm{L})$ and $\mathrm{Mg}^{2+}(40 \mathrm{mg} / \mathrm{L})$ were recorded in Agbowo area, chiefly because the aquifer occurs within melanocratic biotite granite gneiss, rich in biotite and amphiboles.

Nitrate concentration is generally low in both areas. It ranges between 0.80 to $10.80 \mathrm{mg} / \mathrm{L}$. Values greater than 6.5 $\mathrm{mg} / \mathrm{L}$ are recorded only in Agbowo and Apata on the basement complex of Ibadan, and lkotun, ldimu and Shangisha in the sedimentary area of Lagos. Nitrate is a contaminant of major concern in metropolitan areas. It could occur as a consequence of poor sanitation, improper disposal of human and animal wastes or septic tanks. The highest, $\mathrm{NO}_{3}{ }^{-}$value in both areas are below the WHO (1993) and CEC (1980) standards.

According to the World Health Organization (WHO, 1984), high nitrate ingestion can decrease the oxygencarrying capacity of the blood. The concentrations of $\mathrm{Fe}^{2+}$ exceeded the upper limit of $1.0 \mathrm{mg} / \mathrm{L}$ in most of the Lagos water sampled. In the same vein, $\mathrm{Mn}^{2+}$ concentration in about $40 \%$ of the locations exceeded the recommended limit of $0.5 \mathrm{mg} / \mathrm{L}$. This is responsible for the colouration of the water few minutes after collection. The $\mathrm{Fe}^{2+}$ concentration has been implicated in the rusting of water pipes, bad taste and staining problems. In west, Benga, (lndia) iron-rich, alkaline, low- sulphate groundwater was postulated as the cause of arsenic poisoning (arsenicosis) of about 200,000 people. The elevated Na content of the Ibadan and Lagos groundwater is considered harmful to persons suffering from cardiac, renal and circulatory diseases, because it is far above the WHO (1993) recommended limit of $200 \mathrm{mg} / \mathrm{L}$ and the CEC (1980) maximum admissible concentration (Table 3).

The variations noted in the concentration of ions in the groundwater of the study area with respect to the changes in precipitation over the period of sampling are environmentally significant. Higher concentrations were recorded in the samples collected during the dry season of January and February while low concentrations were observed in those of June and July, the peak of the wet season. Neutralization of the aquifer by rainwater in those months is apparent as shown in Figures 6 and 7. The concentration of $\mathrm{Na}^{+}$reduces significantly from $>250 \mathrm{mg} / \mathrm{L}$ in the dry season to about $150 \mathrm{mg} / \mathrm{L}$ in the wet season. Also, $\mathrm{Fe}^{2+}$ and $\mathrm{Mn}^{2+}$ concentrations reduce drastically to values within the WHO (1993) standards in the rainy season. The TDS and $\mathrm{Cl}^{-}$concentration in the coastal sedimentary aquifer of Lagos area also reduces four folds due to increase in the amount of fresh water recharge, which apparently prevent salt-water intrusion. Much lower reduction in TDS and $\mathrm{Cl}^{-}$was recorded in the groundwater of the basement aquifer of lbadan.

\section{Conclusions}

Hydrochemical studies of the groundwater in the basement area of Ibadan and the sedimentary Formation of Lagos show some marked differences in quality with seasons. While the basement water is sodium, calcium bicarbonate species, that of the Lagos sedimentary area is the sodium, calcium chloride and sulphate type. Geological studies show that the $\mathrm{Na}^{2+}$ and $\mathrm{Ca}^{2+}$ in the basement water may be sourced from the weathering of plagioclase feldspars present in the bedrock, while salt-water intrusion may be implicated in the sedimentary area. The four-fold reduction in the $\mathrm{Na}$ and $\mathrm{Cl}$ ions during the wet season in the sedimentary area supports this assertion. Apart from $\mathrm{Na}^{+}, \mathrm{Fe}^{2+}$ and $\mathrm{Mn}^{2+}$, the other ions concentration falls within the WHO (1993) and CEC (1980) recommended maximum value. Na causes foaming, which accelerates scale formation and corrosion in boilers. It is also harmful to people suffering from cardiac, renal and circulatory diseases, which is becoming very widespread in Nigeria. $\mathrm{The}^{2+}$ and $\mathrm{Mn}^{2+}$ on the other hard could create odour, taste and staining problems particularly on textile materials. Though the $\mathrm{NO}_{3}{ }^{-}$content of most of the water samples are within the WHO and CEC recommended standards, there is need for good sanitation and water treatment prior to usage, particularly during the dry season. 


\section{Acknowledgements}

The author is grateful to Prof. S.O. Ajayi and Prof. P.C. Onianwa of the Department of Chemistry, University of lbadan and Prof. A.A. Oladipo of the Centre for Energy Research and Development, Obafemi Awolowo University, Ile-Ife for assisting in laboratory analysis.

\section{Conflict of Interest}

The authors declare that there is no conflict of interest regarding the publication of this paper.
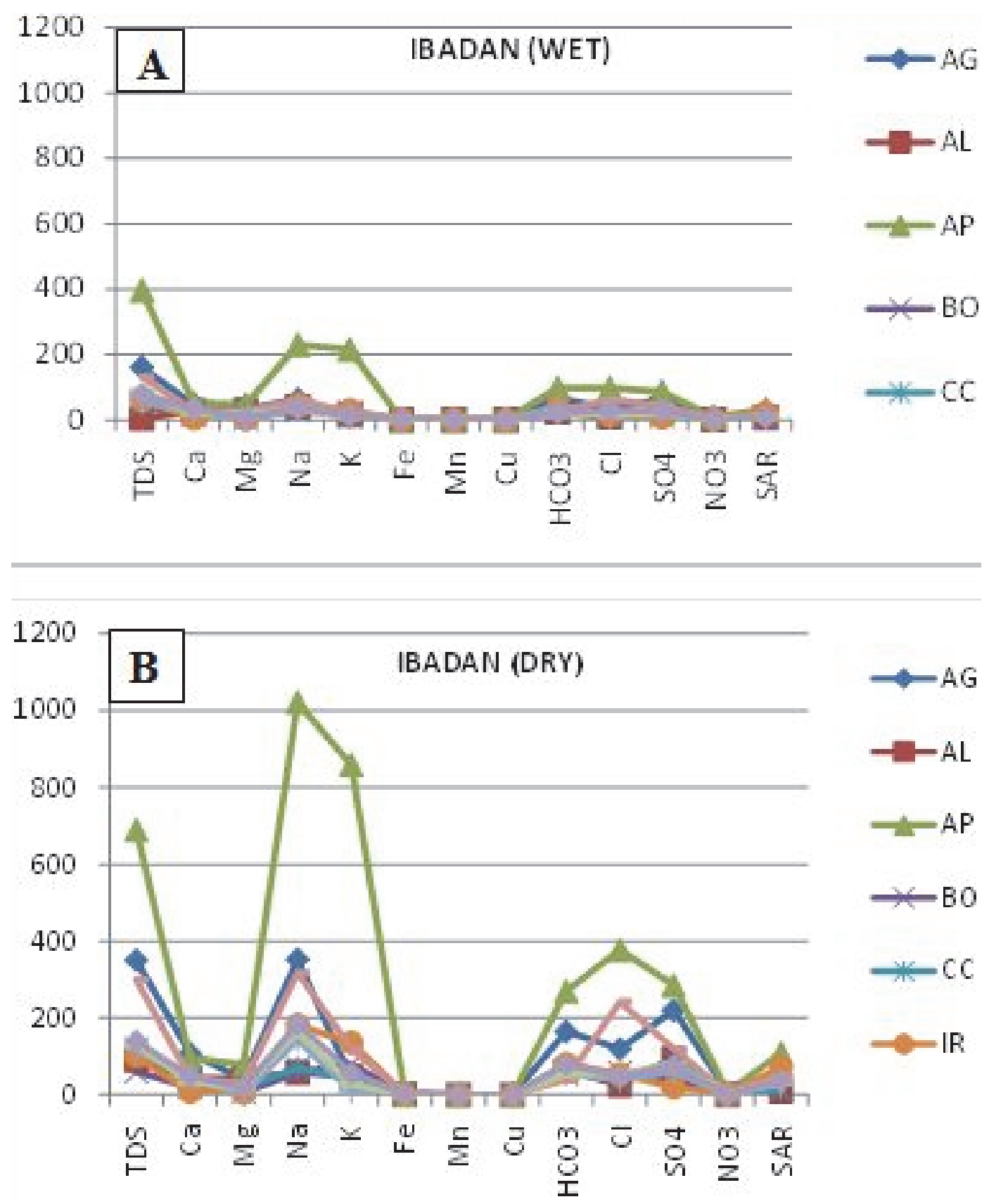

Figure 6. Variations in the chemistry of the groundwater of Ibadan area with seasons

A - Wet season chemical data B - Dry season chemical data 

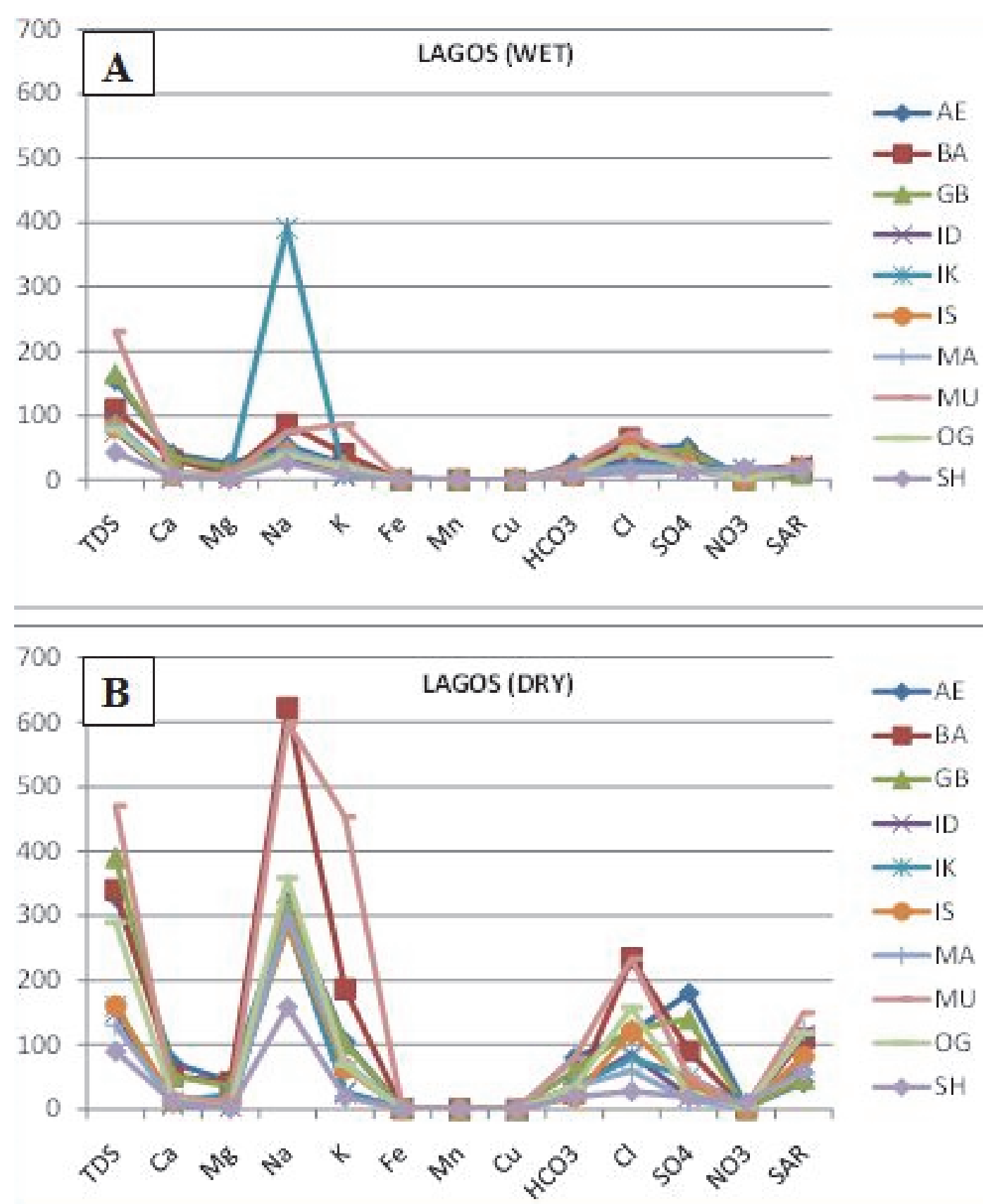

Figure 7. Variations in the chemistry of the groundwater of Lagos area with seasons

A - Wet season chemical data B - Dry season chemical data

\section{References}

Agagu, O. K. (1985). A geologic guide to bituminous sediments in southwestern Nigeria. Department of Geology, University of Ibadan, $16 \mathrm{p}$.

Ako, B. D, Adeniyi, F. I., \& Adepoju, J. F. (1990). Statistical tests and chemical quality of shallow groundwater from a metamorphic terrain, Ile-Ife Modakeke, S.W. Nigeria. Journal of African Earth Science, 10(4), 603613.

Annor, A. E., Olasehinde, P. I., \& Pal, P. C. (1990). Basement fracture patters in the control of water channels, an example from central Nigeria. Journal of Mining Geology, 26(1), 5-8.

APHA-AWWA-WPCF. (1981). Standard methods for the examination of water and wastewater $\left(15^{\text {th }}\right.$ Ed.). 
Washington, D.C., USA, American Public Health Association, 1,134p.

Appleyard, S. J. (1995). The impart of urban Development on recharge and Groundwater quality in a coastal aquifer near Perth, Western Australia. Hydrogeology, 3(2), 65 - 75.

Archeampong, S. Y., \& Hess, J. W. (1998). Hydrogeologic and hydrochemical Framework of the shallow groundwater system in the southern voltaian Sedimentary basin, Ghana. Hydrogeology, l6, 527 - 537.

Asseez, L. O. (1971). Rural water supply in the basement complex of western state, Nigeria. Bulletin of the International Association of Hydrogeological Science, xxii, 141/972, 97 - 111.

Bolarinwa, A. T. (2001). Compositonal characteristics and economic potentials of lateritic profiles over basement and sedimentary rocks in Ibadan - Abeokuta area southwestern Nigeria. Unpublished Ph.D. Thesis, University of Ibadan, Nigeria, 255p.

Brown, E., Skougstad, M. W., \& Fishman, M. J. (1970). Methods for collection and analysis of Water samples for dissolved minerals and gases. US Geological Survey Techniques of water Resources lnvestigations, Book 5, Chapter A-1.

Commision for the European Communities (CEC). (1980). Guideline: In Geology for sustainable development Urban Geology . UNESCO publication. Bulletin(11), 77.

Fayose, E. A. (1970). Stratigraphical paleontology of Afowo-1 well, Southern Nigeria. Journal of Mining and Geology, 5, 1-99.

Idowu, O. A., Ajayi, O., \& Martins, O. (1999). Occurrence of groundwater in parts of the Dahomey Basin, southwestern Nigeria. Journal of Mining Geology, 35(2), 229-236.

Jones, H. A., \& Hockey, R. D. (1964). The geology of Part of southwestern Nigeria. Geological Survey Nigeria Bulleti, 31, 101.

Kacaroglu, F., \& Gunay, G. (1997). Impacts of human activities on groundwater quality of an alluvial aquifer: A case study of the Eskisehir plain, Turkey. Hydrogeology, 5(3), 60-70.

Kampsax, K., \& Sshwed, A. (1977). Underground water resource investigation of the Metropolitan Lagos: Final Report, Federal Ministry of Works and Planning, Lagos.

Kemp, A., \& Hafi, A. (2001). Benefits of increased irrigation efficiency in the Murrumbidgee Irrigation Area. Paper presented at the $45^{\text {th }}$ Annual Conference of the Australian Agricultural and Resource Economics Society, Adelaide, $21 \mathrm{p}$.

Loehnert, E. P. (1981). Groundwater quality aspects of dug wells in southern Nigeria. Proceedings of lnternational Symposium on 'Quality of groundwater” Noordvijikerhout (Amsterdam). March, 1981.

Offodile, M. E. (1983). Occurrence and exploitation of groundwater reserves in basement complex areas. A case study of S.W Nigeria. Journal Mining and Geology, 20(1\&2), 10-20.

Olarewaju, V. O., Olorunfemi, M. O., \& Alade, O. (1997). Chemical characteristics of groundwater from some parts of the basement complex of central Nigeria. Journal of Mining and Geology, 33(2), 135-139.

Olayinka, A. I. (1992). Geophysical sitting of boreholes in crystalline basement areas of Africa. Journal of African Earth Sciences, 14(2), 197 - 207.

Omatsola, M. E., \& Adegoke, O. S. (1981). Tectonic evolution and Cretaceous Stratigraphy of the Dahomey Basin. Journal of Mining and Geology, 18(1), 130 - 137.

Onwuka, M. O. (1989). Geothermal water of Abeokuta Formation. Proc, $25^{\text {th }}$ Annual Conference of the Nigerian Mining and Geosciences Society.

Onwuka, M. O. (1990). Groundwater resources of Lagos State. Unpublished M.Sc. Project Report. University of Ibadan, Ibadan.

Oteri, A. U. (1989). Saltwater intrusion into coastal Aquifers in Nigeria. A review Proceedings of NIWASA Annual Conference, Port - Harcourt, Nigeria, 161-169.

UNESCO (1997-1998). Geology for sustainable development. Urban Geology Bulletin 11, 153p. World Health Organisation (1984). Guidelines for drinking-water quality, Vol .1, Recommendation, Geneva. Switzerland, WHO Publishers.

World Health Organisation. (1984). Guidelines for drinking - water quality, 2-Health criteria and other supporting information: Geneva, WHO Publishers, 335p. 
World Health Organisation. (1993). Guideline. In: Geology for sustainable Development. Urban Geology. UNESCO publication. Bull. 11, p. 77.

\section{Copyrights}

Copyright for this article is retained by the author(s), with first publication rights granted to the journal.

This is an open-access article distributed under the terms and conditions of the Creative Commons Attribution license (http://creativecommons.org/licenses/by/4.0/). 